\title{
PENERAPAN MODEL PEMBELAJARAN TEAM ASSISTED INDIVIDUALIZATION (TAI) DALAM PENINGKATAN AKTIVITAS BELAJAR SISWA PADA MATA PELAJARAN MATEMATIKAKELAS IX-10 SMP NEGERI 4 MEDAN
}

\author{
Isak Ritonga \\ Guru Mata Pelajaran Matematika SMP Negeri 4 Medan \\ Surel : isak.ritonga@gmail.com
}

\begin{abstract}
Abstrak
Penelitian tindakan kelas ini akan ditempuh dalam dua siklus. Dari siklus ke siklus menggunakan model pembelajaran kooperatif tipe TAI dengan senantiasa meningkatkan kualitas pelaksanaan pembelajaran yang berorientasi aktivitas siswa. Siklus I diperoleh nilai rata-rata 64 dengan ketuntasan belajar yang dicapai 35\%. Setelah dilakukan perbaikan pembelajaran pada siklus II diperoleh rata-rata hasil belajar sebesar 87 dengan ketuntasan klasikal mencapai 97\%, karena lebih besar dari $85 \%$ maka siklus II dikatakan berhasil memberikan ketuntasan belajar klasikal. Aktivitas menulis dan membaca turun dari $41 \%$ menjadi $38 \%$, hal ini menunjukkan siswa sudah tidak monoton akan tetapi mulai aktif dalam pembelajaran. Aktivitas mengerjakan dalam diskusi yang meningkat dari $29 \%$ menjadi $37 \%$ menunjukkan perbaikan yang terjadi dalam proses pembelajaran. Sementara aktivitas bertanya pada teman naik dari $13 \%$ menjadi $15 \%$ menunjukkkan siswa sudah mulai aktif dalam berdiskusi dan bertanya pada guru turun dari $8 \%$ menjadi $4 \%$ menunjukkan siswa sudah mulai tidak ketergantungan kepada guru. Aktivitas yang tidak relevan dengan KBM pada turun dari $11 \%$ menjadi $8 \%$.
\end{abstract}

Kata Kunci : Model, TAI (Team Assisted Individualization), Hasil Belajar

\section{PENDAHULUAN}

Ketika kita meminta kepada seorang siswa untuk mengungkapkan pendapatnya tentang pembelajaran Matematika, maka akan banyak terdengar keluhan bahwa pelajaran Matematika membosankan, tidak menarik, bahkan penuh misteri, sehingga berujung pada hasil belajar Matematika yang rendah. Hal tersebut diantaranya disebabkan masih kurangnya kreatifitas guru Matematika sebagai "koki" dalam menyajikan model pembelajaran dan media yang lebih menyenangkan dan dekat dengan dunia siswa. Sebagaimana Arsyad (2006:15) mengemukakan dua unsur yang amat penting dalam proses pembelajaran di kelas yaitu model/strategi dan media pembelajaran. Belajar Matematika dari sumber guru merupakan hal yang banyak dilakukan pada pendidikan formal. Sudjana (2003: 112) menyebutnya sebagai sekolah tradisional. Dimana pola interaksi edukatif dalam proses pembelajaran di kelas masih didominasi oleh guru. Guru masih menjadi satu-satunya sumber belajar bagi siswa. Sementara itu sumber belajar lainnya belum dimanfaatkan secara optimal untuk meningkatkan efektifitas pembelajaran. Menurut Soleh (1998:18) hal tersebut disebabkan kelebihan guru dibanding 
sumber belajar lainnya. Guru lebih mampu mengkondisikan semua sumber belajar lainnya agar sesuai dengan kepentingan dan kemampuan siswa.

Selain guru, buku teks juga masih menjadi sumber belajar yang utama dan mendominasi dalam proses pembelajaran yang dilakukan selama ini. Namun hal ini bukan berarti bahwa buku teks merupakan media yang istimewa. Dalam proses pembelajaran matematika di sekolah terdapat beberapa permasalahan. Terkait dengan karekteristik matematika, objeknya yang abstrak, konsep dan prinsipnya berjenjang, dan prosedur pengerjaannya yang banyak memanipulasi bentuk-bentuk membuat siswa seringkali mengalami kesulitan. Hal ini menuntut peraga yang tepat, yang mampu membantu siswa memahami konsep yang diajarkan dan mampu mengatasi keberagaman kecepatan belajar dan gaya belajar siswa, serta mengatasi keterbatasan yang ada pada guru.

Dewasa ini, kita perlu menelaah kembali praktik-praktik pembelajaran di sekolah-sekolah. Pembelajaran tidak lagi harus menjejali siswa dengan berbagai muatan informasi yang dianggap penting oleh guru. Sehingga siswa cukup mendengarkan ceramah guru dan menjadi pelajar yang pasif. Tetapi lebih dari itu, pembelajaran harus mengupayakan pemahaman siswa melalui proses konstruksi pengetahuan dalam pengalaman belajarnya.
Namun, ada persepsi umum yang menganggap bahwa sudah merupakan tugas guru untuk mengajar dan menyodori siswa dengan muatan-muatan informasi dan pengetahuan. Guru perlu bersikap atau setidaknya dipandang oleh siswa sebagai yang mahatahu dan sumber informasi. Lebih celaka lagi, siswa belajar dalam situasi yang membebani dan menakutkan karena dibayangi oleh tuntutan-tuntutan mengejar nilai-nilai tes dan ujian yang tinggi.

Menyadari tuntutan akan perubahan paradigma pembelajaran terutama dalam pembelajaran Matematika di SMP Negeri 4 Medan peneliti sebagai guru telah menerapkan pembelajaran berpusat pada siswa. Salah satu yang sering diterapkan adalah model pembelajaran kooperatif atau kerja kelompok. Sayangnya, model kerja kelompok sering dianggap kurang efektif. Berbagai sikap dan kesan negatif memang bermunculan dalam pelaksaan kerja kelompok. Jika kerja kelompok tidak berhasil, siswa cenderung saling menyalahkan. Sebaliknya jika berhasil, muncul perasaan tidak adil. Siswa yang pandai atau rajin merasa rekannya yang kurang mampu telah membonceng pada hasil kerja mereka. Akibatnya, kerja kelompok yang seharusnya bertujuan mulia, yakni menanamkan rasa persaudaraan dan kemampuan bekerja sama, justru bisa berakhir dengan ketidakpuasaan dan kekecewaaan. Sedangkan minat 
belajar siswa yang dikembangkan justru terus menurun karena berbagai kesan negatif ini.

Berbagai dampak negatif dalam menggunakan kerja kelompok tersebut seharusnya bisa dihindari jika saja guru mau meluangkan lebih banyak waktu dan perhatian dalam mempersiapkan dan menyusun metode kerja kelompok. Yang diperkenalkan dalam model pembelajaran cooperative learning bukan sekedar kerja kelompok, melainkan pada penstrukturannya. Jadi, sistem pembelajaran cooperative learning bisa didefinisikan sebagai kerja atu belajar kelompok yang terstruktur. Yang termasuk di dalam struktur ini adalah lima unsur pokok (Johnson \& Johnson, 1993), yaitu saling ketergantungan positif, tanggung jawab individual, interaksi personal, keahlian bekerja sama, dan proses kelompok.

Mengatasi keterbatasan peneliti dalam penguasaan teori pembelajaran yang melandasi model koperatif, maka peneliti berkolaborasi dengan guru sejawat yang ada di SMPN 4 Medan. Dengan berkolaborasi dan pembimbingan maka penerapan model pembelajaran kooperatif dapat dilakukan sesuai unsur-unsur yang ada sehingga analisis terhadap tindakan perbaikan pembelajaran tiap siklus dapat dilakukan dengan baik.

Kekawatiran bahwa hasil belajar siswa dalam mengembangkan diri secara individual bisa terancam dalam penggunaan kerja kelompok bisa dimengerti karena dalam penugasan kelompok yang dilakukan secara sembarangan, siswa bukannya belajar secara maksimal, melainkan belajar mendominasi ataupun melempar tanggung jawab. Pembelajaran koperatif didesain sedemikian rupa sehingga masingmasing anggota dalam satu kelompok melaksanakan tanggung jawab pribadinya karena ada sistem akuntabilitas individu. Siswa tidak bisa begitu saja membonceng jerih payah rekannya dan usaha setiap siswa akan dihargai sesuai dengan poin-poin perbaikannya.

Salah satu tipe yang memenuhi tuntutan ini adalah model pembelajaran kooperatif tipe Team Assisted Individualization (TAI). Model ini mengkombinasikan keunggulan pembelajaran kooperatif dan pembelajaran individual. Tipe ini dirancang untuk mengatasi kesulitan belajar siswa secara individual melalui pembelajaran kelompok. Ciri khas pada tipe TAI ini adalah setiap siswa secara individual belajar materi pembelajaran yang sudah dipersiapkan oleh guru. Hasil belajar individual dibawa ke kelompokkelompok untuk didiskusikan dan saling dibahas oleh anggota kelompok, dan semua anggota kelompok bertanggung jawab atas keseluruhan jawaban sebagai tanggung jawab bersama.

Berdasarkan latar belakang masalah yang telah diuraikan dapat diidentifikasi permasalahan yang relevan terhadap pembelajaran Matematika di SMP Negeri 4 
Medan diantaranya: (1)Aktivitas dan hasil belajar Matematika siswa yang masih rendah, (2) Siswa tidak tertarik belajar Matematika karena butuh pemikiran yang lebih ekstra, (3)Ada persepsi yang menganggap bahwa sudah merupakan tugas guru untuk mengajar dan menyodori siswa dengan muatan-muatan informasi dan pengetahuan, Berdasarkan identifikasi masalah, rumusan masalah adalah (1) Apakah terjadi peningkatan aktivitas belajar Matematika siswa setelah diterapkannya model pembelajaran kooperatif tipe Team Assisted Individualization? (2) Apakah terjadi peningkatan hasil belajar setelah diterapkannya model pembelajaran kooperatif tipe TAI?

Adapun tujuan penelitian yang akan dicapai adalah (1) Ingin mengetahui peningkatan aktivitas belajar matematika siswa setelah diterapkannya model pembelajaran kooperatif tipe Team Assisted Individualization. (2) Ingin mengetahui peningkatan hasil belajar Matematika siswa setelah diterapkannya model pembelajaran kooperatif tipe TAI.

\section{METODOLOGI PENELITIAN}

Penelitian ini akan dilaksanakan SMP Negeri 4 Medan yang beralamat di Jalan Jati III No. I18 kelurahan teladan timur. Penelitian ini dilaksanakan pada semester ganjil Tahun Pelajaran 2014/2015 selama 4 (empat) bulan mulai dari bulan September 2014 sampai dengan Desember 2014. Pengambilan data dilaksanakan selama 4 (empat) KBM yang dibagi dalam 2 (dua) Siklus. Subjek penelitian ini adalah siswa kelas IX10 SMP Negeri 4 Medan yang berjumlah 31 siswa. Penelitian ini berbentuk Penelitian Tindakan Kelas (PTK). Penelitian tindakan kelas adalah penelitian yang dilakukan oleh guru di kelas atau di sekolah dengan penekanan pada penyempurnaan atau peningkatan proses pembelajaran. Dalam satu siklus terdiri atas empat langkah, yaitu perencanaan (planning), tindakan (acting), observasi (observing) dan refleksi (reflecting).

\section{HASIL PENELITIAN DAN PEMBAHASAN \\ Deskripsi Awal}

Kondisi awal siswa IX-10 yang menyangkut aktivitas belajar siswa pada mata pelajaran Matematika. Untuk mempertegas identifikasi tersebut dilaksanakan Pretes. Data Pretes menunjukkan nilai terendah 30 dan tertinggi 60 dengan rata-rata 48 dan KKM 75 sehingga ketuntasan belajar secara kalsikal 0\%. Atau kemampuan awal siswa sangat rendah mengindikasikan bahwa siswa tidak membaca buku di rumah untuk materi yang akan dipelajari di sekolah.

\section{Hasil Penelitian Siklus I}

Penilaian aktivitas diperoleh dari lembar observasi aktivitas 
dilakukan pada saat siswa bekerja dalam kelompok diskusi. Pengamatan dilakukan oleh dua pengamat selama 20 menit kerja kelompok dalam setiap kegiatan belajar mengajar (KBM). Hasil observasi aktivitas siswa disajikan dalam tabel 1.

Tabel 1. Skor Aktivitas Belajar Siswa Siklus I

\begin{tabular}{|c|c|c|c|}
\hline No & Aktivitas & Skor & Proporsi \\
\hline 1 & Menulis dan membaca & 20,25 & $41 \%$ \\
\hline 2 & Mengerjakan LKS & 14,25 & $29 \%$ \\
\hline 3 & Bertanya pada teman & 6,25 & $13 \%$ \\
\hline 4 & Bertanya pada guru & 3,75 & $8 \%$ \\
\hline 5 & Yang tidak relevan & 5,5 & $11 \%$ \\
\hline \multicolumn{2}{|r|}{ Jumlah } & 50 & $100 \%$ \\
\hline
\end{tabular}

Setelah berakhirnya pelaksanaan Siklus I diadakan tes hasil belajar siswa yang selanjutnya disebut formatif I. Hasil belajar siswa yang diperoleh pada siklus I selama dua pertemuan disajikan dalam Tabel 2.

Tabel 2. Deskripsi Data Formatif I

\begin{tabular}{|c|c|c|}
\hline Nilai & Frekuensi & Rata-rata \\
\hline 100 & 1 & \\
\cline { 1 - 2 } 80 & 10 & \multirow{2}{*}{6} \\
& \multirow{2}{*}{64} \\
\hline 60 & 14 & \\
\hline 40 & 6 & \\
\hline Jumlah & 31 & \\
\hline
\end{tabular}

Merujuk pada Tabel 2 Siswa dengan nilai terendah (40) sebanyak 6 siswa dan yang mendapat nilai tertinggi (100) sebanyak 1 orang. nilai rata-rata 64 dengan KKM 75 jumlah siswa tuntas 11. Hasil tersebut menunjukkan bahwa pada Siklus I secara klasikal siswa belum tuntas belajar, walaupun rata-rata kelas mencapai 64 karena siswa yang memahami materi yang telah disampaikan hanya sebesar 35\% lebih kecil dari persentase ketuntasan yang dikehendaki yaitu sebesar $85 \%$. Hal ini disebabkan karena siswa masih merasa baru dan belum mengerti apa yang dimaksudkan dan digunakan guru dengan menerapkan model pembelajaran koperatif tipe Team Assisted Individualization (TAI). Dengan demikian maka peneliti berusaha melakukan tindakan perbaikan dalam melaksanakan pembelajaran Siklus II yang dirasa perlu.

\section{Hasil Penelitian Siklus II}

Aktivitas siswa pada Siklus II mengalami peningkatan dibandingkan Siklus I. Hasil pengamatan aktivitas belajar siswa pada siklus II disajikan pada tabel 3.

Tabel 3. Skor Aktivitas Belajar Siswa Siklus II

\begin{tabular}{|c|l|c|c|}
\hline No & \multicolumn{1}{|c|}{ Aktivitas } & Skor & Proporsi \\
\hline 1 & Menulis dan membaca & 18,75 & $38 \%$ \\
\hline 2 & Mengerjakan LKS & 18,5 & $37 \%$ \\
\hline 3 & Bertanya pada teman & 7.75 & $15 \%$ \\
\hline 4 & Bertanya pada guru & 2,5 & $4 \%$ \\
\hline 5 & Yang tidak relevan & 5 & $8 \%$ \\
\hline \multicolumn{2}{|c|}{ Jumlah } & 52,5 & $100 \%$ \\
\hline
\end{tabular}

Diakhir Siklus II diberikan tes hasil belajar sebagai Formatif II 
dengan jumlah soal 4 item. Data Formatif II disajikan dalam Tabel 4.

Tabel 4. Deskripsi Data Formatif II

\begin{tabular}{|c|c|c|}
\hline Nilai & Frekuensi & Rata-rata \\
\hline 100 & 12 & \\
\cline { 1 - 2 } 80 & 18 & \multirow{2}{*}{87} \\
\cline { 1 - 2 } 60 & 1 & \\
\cline { 1 - 2 } Jumlah & 31 & \\
\hline
\end{tabular}

Merujuk pada Tabel 4. Siswa dengan nilai terendah (60) sebanyak 1 siswa dan yang mendapat nilai tertinggi (100) sebanyak 12 orang. nilai rata-rata 87 dengan jumlah siswa tuntas 30. Hal ini menunjukkan siswa mulai memahami penjelasan guru. Hasil tersebut menunjukkan bahwa pada Siklus II secara klasikal siswa sudah tuntas belajar, karena siswa yang memahami materi yang telah disampaikan sebesar $97 \%$ mencapai persentase ketuntasan yang dikehendaki yaitu sebesar $85 \%$.

\section{Pembahasan}

Hasil penelitian menunjukkan perbandingan aktivitas siswa antara Siklus I dengan Siklus II dijabarkan, aktivitas menulis dan membaca turun dari $41 \%$ menjadi $38 \%$, hal ini menunjukkan siswa sudah tidak monoton akan tetapi mulai aktif dalam pembelajaran. Aktivitas mengerjakan dalam diskusi yang meningkat dari 29\% menjadi 37\% menunjukkan perbaikan yang terjadi dalam proses pembelajaran. Sementara aktivitas bertanya pada teman naik dari $13 \%$ menjadi $15 \%$ menunjukkkan siswa sudah mulai aktif dalam berdiskusi dan bertanya pada guru turun dari $8 \%$ menjadi $4 \%$ menunjukkan siswa sudah mulai tidak ketergantungan kepada guru. Aktivitas yang tidak relevan dengan $\mathrm{KBM}$ pada turun dari $11 \%$ menjadi 8\%. Hasil belajar kognitif pada Siklus I diperoleh nilai rata-rata 64 dengan ketuntasan belajar yang dicapai 35\%, karena kurang dari $85 \%$ siklus I dikatakan tidak tuntas. Setelah dilakukan perbaikan pembelajaran pada siklus II diperoleh rata-rata hasil belajar sebesar 87 dengan ketuntasan klasikal mencapai 97\%, karena lebih besar dari $85 \%$ maka siklus II dikatakan berhasil memberikan ketuntasan belajar klasikal.

Berdasarkan pengamatan aktivitas belajar dan hasil belajar kognitif Siklus I menunjukkan bahwa masih terdapat beberapa permasalahan/kekurangan dalam pelaksanaan tindakan yang perlu diperbaiki secara lanjut. Beberapa kelemahan pada Siklus I terlihat dari aktivitas siswa dalam mengikuti pembelajaran, diantaranya:

a. Pengelolaan pembelajaran yang dilkukan guru masih kurang baik terutama pada aspek-aspek menjelaskan langkah pembelajaran, membimbing siswa melakukan kegiatan presentasi, membimbing siswa mendiskusikan hasil kegiatan dalam kelompok, memberikan kesempatan pada siswa untuk mempresentasikan, dan pengelolaan waktu. 
b. Tanggung jawab individu dalam kelompok kooperatif tipe TAI masih kurang.

c. Kekompakan kerja kelompoknya masih kurang.

d. Minat belajar siswa masih kurang.

e. Secara umum pembentukan kelompok masih kurang baik.

f. Suasana pembelajaran kurang kondusif.

g. Dalam mengerjakan tugas di depan kelas siswa kurang berani.

h. Dalam menyelesaikan soal secara individu masih ada siswa yang belum tuntas.

i. Keinginan siswa dalam bertanya sesama teman masih kurang lebih banyak kepada bertanya kepada guru.

Untuk mengatasi berbagai kelemahan Siklus I yang teridentifikasi dalam refleksi maka akan dilakukan tindakan perbaikan diantaranya :

a. Keterampilan guru dalam mengelola pembelajaran kooperatif tipe TAI dianalisis dan diperbaiki kembali terutama pada aspek yang masih lemah.

b. Kelompok dibentuk kembali dengan mempertimbangkan komposisi siswa dalam menjamin heterogenitasnya untuk meningkatkan tanggung jawab individu.

c. Tugas-tugas dikumpulkan dengan cara penagihan tiap individu ini untuk meningkatkan tanggung jawab dan kemampuan siswa dalam menyelesaikan tugas.

d. Memberikan motivasi dan semangat agar siswa menjadi lebih aktif dan menimbulkan keberanian siswa mengerjakan tugas di depan kelas.

e. Pada tiap akhir pertemuan, guru memberikan PR untuk mengukur kemandirian siswa dalam belajar dan mengukur kemampuan siswa memahami materi.

f. Dalam penyampaian materi dilakukan induksi dengan memberikan pertanyaan dan jawabannya yang bergam ditulis di papan tulis untuk diambil kesimpulan umum sehingga siswa memiliki keterampilan berpikir menginduksi.

g. Setiap pertanyaan siswa tidak langsung dijawab oleh guru melainkan dilemparkan terlebih dahulu pada siswa lain sehingga diskusi dan aktivitas bertanya pada siswa meningkat dan ketergantungan siswa pada guru menurun.

Melalui tindakan perbaikan yang dilakukan pada Siklus II pembelajaran menggunakan model kooperatif tipe TAI memberikan ketuntasan belajar matematika siswa pada Siklus II. Pembelajaran kooperatif tipe TAI selain memperbaiki aktivitas belajar siswa ternyata juga telah mampu menumbuhkan minat belajar siswa terhadap pembelajaran matematika yang berimplikasi pada 
meningkatnya ketuntasan hasil belajar siswa.

Bantuan belajar oleh teman sebaya dapat menghilangkan kecanggungan, lebih mudah dipahami, tidak ada rasa enggan, rendah diri, malu dan sebagainya untuk bertanya ataupun minta bantuan. Seperti yang dikemukakan oleh Longstreth (Suherman, dkk. 2003 : 277) tentang hubungan anak dengan anak sebagai berikut:

"Interaksi kawan membukakan mata anak terhadap pola tingkah laku yang berlaku dalam kebudayaan itu, yang sering dilakukan dan dengan demikian ia condong untuk mempelajari bentuk-bentuk tingkah laku yang dipakai untuk pergaulan yang berlaku".

Pembelajaran kooperatif tipe TAI adalah kegiatan yang kaya akan pengalaman yang justru sebenarnya merupakan kebutuhan anak itu sendiri. Siswa berusaha mencari perannya sendiri, mengembangkan kecakapan intelektual dan konsepkonsep yang penting, mendapatkan tingkah laku yang bertanggung jawab secara individu. Dengan demikian beban yang diberikan kepada mereka akan memberikan kesempatan untuk mendapatkan perannya, bergaul dengan orang lain, dan bahkan mendapatkan pengetahuan dan pengalaman.

\section{SIMPULAN DAN SARAN}

Setelah data-data tes hasil belajar, dan aktivitas belajar siswa terkumpul kemudian data tersebut dianalisis. Hasil analisis tersebut dapat disimpulkan pembelajaran matematika di kelas IX-10 SMP Negeri 4 MedanTahun Pelajaran 2014/2015 sesuai dengan rumusan masalah, yaitu;

a. Hasil belajar kognitif pada Siklus I diperoleh nilai rata-rata 64 dengan ketuntasan belajar yang dicapai 35\%, karena kurang dari $85 \%$ siklus I dikatakan tidak tuntas. Setelah dilakukan perbaikan pembelajaran pada siklus II diperoleh rata-rata hasil belajar sebesar 87 dengan ketuntasan klasikal mencapai 97\%, karena lebih besar dari $85 \%$ maka siklus II dikatakan berhasil memberikan ketuntasan belajar klasikal.

b. Aktivitas belajar siswa adapat kita jabarkan sebagai berikut; aktivitas menulis dan membaca turun dari $41 \%$ menjadi $38 \%$, hal ini menunjukkan siswa sudah tidak monoton akan tetapi mulai aktif dalam pembelajaran. Aktivitas mengerjakan dalam diskusi yang meningkat dari $29 \%$ menjadi $37 \%$ menunjukkan perbaikan yang terjadi dalam proses pembelajaran. Sementara aktivitas bertanya pada teman naik dari $13 \%$ menjadi $15 \%$ menunjukkkan siswa sudah mulai aktif dalam berdiskusi dan bertanya pada guru turun dari $8 \%$ menjadi $4 \%$ menunjukkan siswa sudah mulai tidak ketergantungan kepada guru. Aktivitas yang tidak relevan 
dengan KBM pada turun dari $11 \%$ menjadi $8 \%$. Sehingga dapat dikatan aktivitas Siklus II lebih baik dari pada Siklus I, atau pembelajaran berhasil memperbaiki minat belajar siswa.

\section{DAFTAR RUJUKAN}

Ambary, Abdullah, dkk. 1999.

Penuntun Belajar

Matematika

Menyenangkan

Yang

dan

Petunjuk guru. Bandung:

Trigenda Karya.

Arikunto, Suharsimi. 1997. Dasardasar Evaluasi Pendidikan. Jakarta: Bumi Aksara.

Joyce, Bruce dan Weil, Marsh. 1972. Models of Teaching Model. Boston: A Liyn dan Bacon.

Lie, Anita. 2005. Cooperative

Learning Mempraktikkan Cooperative Learning di Ruang-ruang Kelas. Jakarta: Grasindo.

Soleh, M. 1998. Pokok-Pokok

Pengajaran Matematika Sekolah. Depdikbud. Jakarta.

Santosa, K. 2002. Pemilihan dan Pengembangan Media

Pembelajaran. Makalah Pelatihan Desain

Pembelajaran. BPG

Semarang.

Sujana, N. 2003. Teknologi Pengajaran. Sinar Baru Algensindo. Bandung.

Marpaung, Y. 2006. Pembelajaran Matematika dengan Model
PMRI.

Makalah.

http://hiqzalmathematic.blo

gspot.com/2010/05/makalah pembelajaran-

matematika.html

Ritonga, Isak. 2014. Perbaikan Hasil Belajar Matematika dengan Model Pembelajaran Team Assisted Individualization. (PTK) Karangan Sendiri. 
